MACIEJ WALCZAK

Uniwersytet Śląski

(iD)

ORCID 0000-0001-6313-5672

\title{
Imiona pochodzenia hebrajskiego w rosyjskich i polskich przysłowiach i powiedzeniach
}

The given (first) names of the Hebrew origin in the Russian and Polish proverbs and sayings

Summary: The article deals with the analysis of the Russian and Polish paremiological units which in their structure contain the first names of Hebrew origin. Upon the proper idiom material the author shows their diversity both in the morphological and word-formative respect especially in Russian language with a high frequency of hypocoristic derivatives. The other respect is of functional and semantic character and it is reflected in the wide topical spectrum of proverbs containing Hebrew first names. Those proverbs describe not only a human beings' character but also his behaviour, the phenomena of nature, extra-linguistic situations, customs and rituals.

Keywords: proverb, saying, anthroponym, Hebrew first names, Russian language, Polish language

Личные имена древнееврейского происхождения в русских и польских пословицах и поговорках

Резюме: В статье анализируются русские и польские паремиологические единицы, в составе которых присутствуют имена древнееврейского происхождения. Показывается их разнообразие как в морфолого-словообразовательном отношении, проявляющемся особенно в русском языке через высокую частотность уменьшительно-ласкательных производных, так и функционально-смысловом, находящем своё выражение в широком тематическом спектре паремий, характеризующих не только человеческие черты характера и поведение, но также и явления природы, внеязыковые ситуации, обычаи и обряды.

Ключевые слова: пословица, поговорка, антропоним, древнееврейские имена, русский язык, польский язык

Do wyboru wspomnianej w tytule problematyki skłoniła nas wysoka frekwencja jednostek paremiologicznych z komponentami antroponimicznymi zaobserwowana w języku rosyjskim i polskim. Zwrot ku wybranemu zagadnieniu wynika również z jego aktualności i wieloaspektowości, o czym świadczyć może bogata literatura przedmiotu', w której zagadnienia imion i specyfiki ich nadawania

Istniejąca obszerna literatura z danego zakresu nie pozwala na wymienienie wszystkich pozycji, w związku z czym przywołamy te prace, które wraz z wymienionymi w dalszej części artykułu posłużyły jako baza 
analizowane były także z pozycji psychologii. Okazuje się bowiem, że różne imiona posiadają odmienne nacechowanie konotacyjne, co w konsekwencji nierzadko determinuje częstotliwość ich nadawania. Co ciekawe, w krajach anglosaskich imiona hebrajskiego pochodzenia, np. Moses, Solomon, Abraham, Joshua, Jacob, należą do grupy najwyżej ocenianych imion pod względem moralnościowym, zaś imiona Joseph, Jonach implikują ciepło i pogodę - ma się rozumieć, w sensie osobowościowo-charakterologicznym².

Imiona hebrajskiego pochodzenia często trafiały do polszczyzny i ruszczyzny za pośrednictwem tekstów Pisma Świętego w wersji łacińskiej lub greckiej, w których to wersjach ulegały pewnym asymilacyjnym modyfikacjom. Wspomniana okoliczność tłumaczy także dużą liczbę imion hebrajskich o rodowodzie biblijnym, zwłaszcza w języku rosyjskim. Zjawisko to szczególnie nie dziwi, ponieważ, jak zauważa Marija Kowszowa za Jurijem Stiepanowem, imiona biblijne na długie wieki przesądziły o kształcie przestrzeni antroponimicznej rosyjskiej kultury i jej związku z rosyjską konceptosferą ${ }^{3}$. Podobnie ujmuje to Krystyna Długosz-Kurczabowa w odniesieniu do języka polskiego, twierdząc, że wielki wpływ Biblii zaznaczył się w dziedzinie onomastyki, a w antroponimii w szczególności ${ }^{4}$. Na istotną rolę biblijnych nazw własnych, szczególnie imion, w kształtowaniu polskiego zasobu leksykalnego zwraca także uwagę Kazimierz Ożóg, wskazując, że często stawały się one swoistymi etykietkami różnych sytuacji ${ }^{5}$. Jak zauważa Jelena Konickaja, imiona biblijne są atrakcyjnym obiektem badań szczególnie w perspektywie porównawczej: ich analiza bowiem pozwala wniknąć w specyfikę sfery idiomatycznej konkretnej narodowo-kulturowej wspólnoty na tle innego języka6 ${ }^{6}$ O randze zja-

teoretyczna naszych rozważań: М.Л. Ковшова, Лингвокультурологический анализ идиом, загадок, nословиц и поговорок, URSS, Москва 2019; Т. Шутковски, Паремийные единищы с ономастическим компонентом в современных русском и польском языках, M. Aleksiejenko (red. nauk.), Volumina.pl Daniel Krzanowski, Szczecin 2010; W. Chlebda, Имя во фразеологии - имя как фразеологизм, w: Имињата и фразеологијата, Филолошки факултет „Блаже Конески", Скопје 2018, s. 15-24; Ю. А. Рылов, Имена собственные в европейских языках. Романская и русская антропонимика, АСТ: Восток-Запад, Москва 2006; Ю.К. Волошин, Онимы в фразеологии, «Актуальные проблемы филологии и педагогической лингвистики» 2017, nr 2, s. 125-132.

2 Zob. K. Doroszewicz, Psychologiczne aspekty imion ludzkich, "Psychologia Jakości Życia” 2003, t. 2, nr 1, s. $90-91$.

3 Zob. М.Л. Ковшова, Лингвокультурологический анализ идиом..., s. 134.

4 Zob. K. Długosz-Kurczabowa, Biblizmy w języku polskim , „Napis” 1994, seria I, s. 28.

5 Zob. K. Ożóg, Ślady kultury żydowskiej w języku polskim, „Kwartalnik Edukacyjny” wiosna 2010, nr 1 (60), s. 6.

6 Zob. Е. Коницкая, Библейские фразеологизмы в русской и литовской фразеологии, w: Rojena v narečje. Akademkinji prof. dr. Zinki Zorko ob 80-letnici, Mednarodna založba Oddelka za slovanske jezike in književnosti — Filozofska fakulteta v Mariboru, Maribor-Bielsko-Biala-Budapest-Kansas-Praha 2016, s. 584-599. 
wiska świadczyć może również ciągłe zainteresowanie problematyką biblizmów oraz imion biblijnych wśród rosyjskich i polskich badaczy?.

Wspomniana wysoka frekwencja paremii z komponentami antroponimicznymi, zdaniem lingwistów, wynika z tego, że antroponimy przekazują i odzwierciedlają niezwykle złożone spektrum kategorii imion, co związane jest z historią danej kultury, jej właściwościami psychologicznymi, tradycją i wieloma innymi czynnikami $^{8}$. Jak zauważają Natalia Dorodniewa i Jelena Jermakowa, tradycyjne imiona, zarówno męskie jak i żeńskie, najlepiej reprezentują kulturę i językowy obraz świata różnych narodów9. Włączenie antroponimu do struktury przysłów i powiedzeń, według Olgi Twierdochlieb, niekiedy motywowane jest celowym zabiegiem rymotwórczym, o czym może świadczyć szereg przysłów o analogicznej budowie składniowej z wzajemnie rymującymi się antroponimami ${ }^{10}$. Zdaniem Margarity Nadel-Czerwińskiej, nazwy własne biorą aktywny udział w procesie tworzenia jednostek paremiologicznych i krótkich tekstów, przy czym w rosyjskiej paremiologii szczególnie aktualne są antroponimy włącznie z jednostkami od nich pochodnymi. Podstawowa ich funkcja sprowadza się zatem do pośredniego odwołania do nosiciela danego imienia, jego cech charakterystycznych, przyzwyczajeń zarówno pozytywnych, jak i negatywnych, będąc niejednokrotnie odbiciem ukształtowanych w ludowo-folklorystycznej tradycji stereotypowych, po części również mitologicznych wyobrażeń o nosicielach określonych imion ${ }^{11}$. W konsekwencji użyty w strukturze idiomów antroponim,

7 Zob. K. Długosz-Kurczabowa, Nowotestamentowe antroponimy w języku polskim, "Poradnik Językowy” 1990, nr 8, s. 605-614; Tejże: Onomastyka Nowego Testamentu, "Slavia Occidentalis" 1989, 69, t. 46/47, s. 71-88; V. Mokienko, Русские библеизмы в европейском контексте , „е̨̨zykoznawstwo" 2018, nr 1(12), s. 33-45; А.В. Григорьев, Библейские фразеологизмы в контексте культуры Ближнего востока, w: В.Н. Телия (red.), Культурные слои во фразеологических и дискурсивных практиках, Языки славянской культуры, Москва 2004, s. 125-131; В.Г. Гак, Особенности библейских фразеологизмов в русском языке (в сопоставлении с французскими библеизмами), «Вопросы языкознания» 1997, nr 5, s. 55-65; S. Koziara, Polska frazeologia biblijna. Stan i perspektywy opisu, "Ling Varia” 2006, rok I, nr 1, s. 73-80; Tegoż: O niektórych wyznacznikach normy w zasobach polskiej frazeologii pochodzenia biblijnego, w: D. Kowalska (red.), Autorytety inormy, Archidiecezjalne Wydawnictwa Łódzkie, Łódź 2003, s. 243-252.

8 Zob. Г. Фей, Имена собственные в русской и китайской фразеологии (магистерская работа), Уральский федеральный университет имени первого Президента России Б.Н. Ельцына, Екатеринбург 2015.

9 Zob. Н.В. Дороднева, Е.Н. Ермакова, Лингвокультурологические свойства фразеологизмов с компонентом-именем собственным (на материале русского и английского языков), «Вестник ЧГПУ. Филология и искусствоведение» 2013, nr 1, s. 236-246.

10 Zob. О.Г. Твердохлеб, Рифмовка личных имен собственных в русских пословицах (преднамеренность рифмовки, грамматические особенности и модели пословии), «Ученые записки Петрозаводского государственного университета» 2016, nr 7-1 (160), s. 67-71.

11 Zob. M. Надель-Червинская, Личные имена русской паремиологии. Лингвокультурологический словарь, Крок, Тернополь 2011, s. 4-5. 
według Marii Wozniesienskiej, traci niejednokrotnie swoją funkcję bezpośredniej identyfikacji i indywidualizacji obiektu'12. Do podobnych wniosków dochodzi również Tomasz Szutkowski, zauważając, że relacja odpowiedniości pomiędzy elementem onomastycznym w danej jednostce paremiologicznej a jego pierwotnym etymonem zaciera się, powodując konieczność odwołania się do danych historyczno-etymologicznych ${ }^{13}$.

Dlatego też imiona własne pochodzenia hebrajskiego w wybranych do analizy paremiach z punktu widzenia współczesnej świadomości językowej użytkowników języka polskiego i rosyjskiego niejednokrotnie postrzegane są jako tradycyjnie swojskie i rodzime. Wielowiekowe funkcjonowanie niektórych z omawianych imion, zwłaszcza w rosyjskiej lingwokulturze, doprowadziło bowiem do całkowitej ich asymilacji i adaptacji w systemach obu języków, przez co związek owych antroponimów z językiem ich pochodzenia nie jest już tak wyraźny i dostrzegalny. $O$ asymilacji niektórych z tych imion niewątpliwie świadczyć może duża ilość form hipokorystycznych (np. pol. Michał - Michatek, Michaś, Michaszek, Mikuś, Misiek, Misio, Miklaś, Micho, Miluś czy ros. Muхauл - Миша, Мишуня, Мишутка, Мишуля, Мики, Миня $\left.{ }^{14}\right)$.

Warto jeszcze poświęcić jeszcze kilka słów kwestii zawartego w tytule artykułu sformułowania imiona pochodzenia hebrajskiego i jego relacji względem pojęcia imiona pochodzenia biblijnego spotykanego w wielu opracowaniach lingwistycznych z tego zakresu tematycznego. Jak się wydaje, imiona pochodzenia biblijnego / imiona biblijne są pojęciowo szersze, jeśli za kryterium wyjściowe obrać źródło nominacji, jako że imiona pochodzenia hebrajskiego / imiona hebrajskie wraz z imionami aramejskimi zaliczane są właśnie do imion biblijnych (staro- i nowotestamentowych, jeśli pojmować Biblię w tradycji chrześcijańskiej jako Stary Testament i Nowy Testament). Różnica pomiędzy interesującymi nas pojęciami sprowadzać się może zatem do wskazania na tekst literacki jako kulturowe źródło badanych jednostek — imiona biblijne - zaś w przypadku imion hebrajskich do wskazania na ich genezę językową i właściwości czysto lingwistyczne. Ponieważ

12 Zob. М.М. Вознесенская, Иван да Марья в русской идиоматике, ш: Л.А. Вербицкая, Л. Лиминь, Е.Е. Юрков (ред.) Русскийязык и литература во времени и пространстве, t. 2, МАПРяЛ, Шанхай 2011, S. 83-87.

${ }_{13}$ Zob. T. Szutkowski, Jednostkiparemiologicznez komponentem onomastycznym w praktyce leksykograficznej (współczesnośći perspektywy), «Проблемы истории, филологии, культуры» 2009, nr 2 (24), s. 35.

14 Pełniejszy wykaz wariantów tego imienia wraz z omówieniem ich właściwości morfemowosłowotwórczych przedstawiony został w książce Piotra Czerwińskiego: П. Червинский, Формы личных имён русского речевого употребления. Обиходно-нейтральные образования и некоторые их производные, Wydawnictwo Uniwersytetu Śląskiego, Katowice 2012, s. 164. 
prezentowany artykuł ma w założeniach taki właśnie charakter, zdecydowaliśmy się na użycie sformułowania imiona pochodzenia hebrajskiego. Na jego korzyść przemawia naszym zdaniem i ta okoliczność, że nie wszystkie omawiane przez nas imiona będą miały rodowód bezpośrednio biblijny, ale wszystkie zaś będą pochodzenia hebrajskiego (rzadko aramejskiego). Trzeba w związku z tym zauważyć, że w języku rosyjskim i polskim wariant biblijny imienia niekiedy różni się od wariantu spotykanego w codziennym, potocznym obiegu językowym (por. ros. Иеремия vs Еремей, Авраамий / Авраам vs Абрамий, Абрам; polsk. Jeremiasz vs Jeremi, Jarema).

Zestawiając materiał rosyjski i polski, można dostrzec dużą różnicę ilościową na korzyść języka rosyjskiego nie tylko pod względem liczby samych jednostek paremiologicznych z hebrajskimi imionami, lecz także wszelkich wariantów imion w nich występujących $^{15}$. Ma to swoje uzasadnienie językowo-kulturowe, ponieważ w języku rosyjskim imiona wydają się pełnić znacznie szersze funkcje niż tylko indywidualizacji obiektu. Ulegają one często apelatywizacji, tworząc - jak wspominaliśmy wyżej — dość liczną grupę nazw określonych typów ludzkich ze względu na stereotypowo przypisywane im cechy pozytywne lub negatywne (por. znane z historii literatury rosyjskiej pierwowzory bohaterów, których nazwiska weszły do języka jako nazwy określonych ludzkich typów: хлестаковы, чичиковы, обломовы). I nie chodzi tutaj o zapelatywizowane imiona typu uудa obecne w wielu językach i kulturach w podobnym znaczeniu, lecz antroponimy w swych znaczeniach wtórnych ukształtowane wyłącznie na gruncie języka rosyjskiego i utrwalone $\mathrm{w}$ jednostkach o charakterze idiomatycznym, np.: фаля, фалалей 'głupi, ograniczony człowiek' od Фалалей / Фалалёй, фофран 'ts' — od Феофан, ванька 'ts' —od Иван, адам - 'ogólnie człowiek, zwłaszcza grzeszny, skłonny do grzechu'16 (por. Ни от камени мёду, ни от фофана плоду; Собой-то краля, а умом-то фаля; Валять ваньку; И ты адам, и я адам, все мы адамы), a także leksemy typu матрёшка — od Матрёна, параша — od Прасковья. I choć w języku polskim od-

15 Przy ustalaniu pochodzenia i etymologii interesujących nas imion wykorzystywaliśmy następujące źródła: I. Marković, Wielka księga imion, Europa, Wrocław 2003; W. Kopaliński, Słownik wyrazów obcych izwrotów obcojęzycznych z almanachem, Wiedza Powszechna, Warszawa 1998; Н.А. Петровский, Словарь русских личных имён, Советская Энциклопедия, Москва 1966. Słownik dostępny jest także w wersji online: https://azbyka.ru/deti/slovar-russkih-lichnyh-imen-petrovskij [10.08.2019]; В.А. Никонов, Ищем имя, Советская Россия, Москва 1988; А.В. Суперанская, Современный словарь личных имён, Айрис Пресс, Москва 2005.

16 Por. В. Даль, Толковый словарь живаго великорускаго языка, t. 1: А-3, Изданіе книгопродавцатипографа М.0. Вольфа, Санктъ-Петербургъ-Москва 1880, s. 5. 
najdziemy podobne apelatywa (np. michałek, miś, mosiek, ze$n e k$ ), to na gruncie paremiologii i frazeologii polskiej nie są one tak rozpowszechnione i licznie utrwalone. Największą z kolei grupę w języku polskim stanowią imiona świętych, obecne również w języku rosyjskim, choć już nie równie częste, w strukturze przysłów związanych z określonym cyklem prac polowych, zjawisk pogodowych, obyczajów, obrzędów przypadających na dzień danego świętego ${ }^{17}$. Najmniejszą grupę w obu językach stanowią imiona postaci biblijnych w paremiach, które są dość mocno osadzone w kontekście religijnym i nawiązują do cech i właściwości pierwotnych nosicieli tych imion (głównie Adam i Ewa), choć i pod tym względem język rosyjski okazuje się od polskiego bogatszy.

Rosyjski materiał badawczy został zaczerpnięty głównie ze zbioru Пословищы русского народа Władimira Dala' ${ }^{18}$ oraz słownika Marii Kowszowej Словарь собственных имён в русских загадках, пословицах, поговорках и идиомах ${ }^{19}$, polski zaś z Wielkiej księgi przysłów polskich Danuty i Włodzimierza Masłowskich ${ }^{20}$ oraz Nowej księgi przysłów i wyrażeń przysłowiowych polskich pod redakcją Juliana Krzyżanowskiego ${ }^{21}$. Ponieważ język rosyjski przyjmujemy tu za podstawę rozważań i punkt wyjścia do porównań z językiem polskim, kolejność prezentacji materiału będzie podporządkowana kryterium malejącej częstotliwości danych imion w materiale rosyjskim. W niniejszym artykule zaprezentowane zostaną tylko te imiona, które w materiale badawczym wykazały największą częstotliwość (powyżej 10 jednostek paremiologicznych z danym imieniem).

W języku rosyjskim szczególną aktywnością odznacza się imię Фома, które co prawda przeszło doń z greki (от греч. $\Theta \omega \mu$ ác), to ma jednak korzenie aramejskie: אמופ 'bliźniak' i jest wschodniosłowiańskim odpowiednikiem polskiego wariantu imienia Tomasz. Ze względu na wspomnianą dużą liczbę przysłów przytaczamy tylko wybrane - w słowniku Marii Kowszowej zarejestrowano 120 jednostek paremiologicznych z tym imieniem i jego pochodnymi, np.: Фомище / Фомка / Фомушка / Фомка Фома / Фомушка

17 w polskiej literaturze lingwistycznej podobne paremie określane są także mianem przysłów kalendarzowych, por. I. Steczko, Przysłowia $i$ wyrażenia przysłowiowe z imieniem Anna, „Annales Universitatis Paedagogicae Cracoviensis" 2015, Studia Linguistica X, s. 186.

18 В. Даль, Пословицы русского народа, ЭКСМО-Пресс, Москва 2000.

19 М.Л. Ковшова, Словарь собственных имён в русских загадках, пословицах, поговорках и идиомах, URSS, Москва 2019.

20 D. i W. Masłowscy, Wielka księga przysłów polskich, Klub dla Ciebie, Warszawa 2008.

21 J. Krzyżanowski (red.), Nowa księga przysłów i wyrażeń przysłowiowych polskich, Państwowy Instytut Wydawniczy, Warszawa 1969-1972. 
Фома / Хома ${ }^{22}$. Imię to występuje w paremiach charakteryzujących, m.in.

\section{Bogactwo ${ }^{23}$}

Фома - большая крома (przypadający 6 października według kalendarza juliańskiego lub 19 według kalendarza gregoriańskiego dzień św. Fomy miał zwiastować obfitość plonów i zapasów)

\section{Rozum i głupotę}

Фома не без ума, Ерёма не без промысла

Ждут Фому: чают быть уму

Фома не купит ума, своего продаст

Молод Фома, а голова без ума

Читай Фома, набирай ума ${ }^{24}$

\section{Dostatek - ubóstwo}

В худе городе / на худом городе и Фома дворянин

На безлюдье и Фома дворянин

От горя, от нужи и Фома дворянин

Не все коту масленица, попу Фомин понедельник

\section{Swoje - cudze}

Зовут меня фомой, а живу я собой

Ищи Фома, чтоб полна была сума

Это знать тому, кто знает Фому

W języku polskim zanotowaliśmy kilka jednostek paremiologicznych z imieniem Tomasz oraz wariantami Tomek, Toma, Tomas dotyczących głównie przesądów i wróżb pogodowych oraz zjawisk astronomicznych przypadających na dzień danego świętego: Gdy na Tomasza pada, zmienna zimę zapowiada; Gdy w Tomasza pogoda, zima silne wiatry poda; Jaka pogoda Tomaszowa, taka będzie i majowa; Na świętego Tomasza dzień się z noca sili: mniej nocy, więcej dnia będzie po chwili; W Tomasza najdłuższa noc nasza; Niech cię nawet na Tomasza twój siew żyta nie odstrasza;

22 М.Л. Ковшова, Словарь собственных имён..., s. 191-194.

23 Podstawę podziału tematycznego paremii rosyjskich przyjmujemy za Dalem. Należy jednak zaznaczyć, że ów podział, stworzony jeszcze w XIX w. i przez to odzwierciedlający w dużej mierze wyobrażenia dziewiętnastowieczne, wymagałby miejscami reinterpretacji i aktualizacji w związku z nowszymi oraz dokładniejszymi opracowaniami danego zagadnienia (zob. nр. Г. Л. Пермяков, От поговорки до сказки (замечания по общей теории клише), Издательство «Наука», Москва 1970, s. 131-199). w związku z tym, że celem niniejszego artykułu nie było stworzenie nowego podziału tematycznego paremii, pozostawiamy go w wersji zaproponowanej przez Dala.

24 Kwestia imion pochodzenia greckiego i hebrajskiego w rosyjskich przysłowiach ludowych związanych z rozumem i głupotą szczegółowo została omówiona w pracy: М. Вальчак, Заимствованные элементы в русских народных пословицах и поговорках, относящихся к уму и глупости, w: Х. Вальтер, В. М Мокиенко (red.), Славянская фразеология: заимствования и кальки в славянской фразеологии, Лема, Санкт-Петербург 2020 (w druku). 
Na świętego Tomasa wyrasta w polu pasa; Na świętego Toma będa wieprze doma. Oprócz tego w polskim zasobie paremiologicznym odnajdujemy jednostki związane z takimi cechami i polami tematycznymi, jak:

\section{Osiąganie i otrzymywanie określonych korzyści — dawanie innym}

Lepszy To-masz niż Ja-dam (gra słów na bazie imion Tomasz i Adam)

Lepszy To-masz niż nie-masz

Łapaj Tomku, póki na pomku

\section{Sposób zachowania - obyczaj}

Nie powiadaj, Toma, co się dzieje doma

Największy Toma, gdy doma

Mawiał święty Tomasz: jedz doma, co masz, a u ludzi, coć dadza.

Wyrażenie Wolnoć Tomku w swoim domku nie zostało wzięte pod uwagę, ponieważ należałoby zaliczyć je bardziej do skrzydlatych słów (jako cytat z wiersza Aleksandra Fredry) niż do przysłów i powiedzeń, choć rejestruje go Nowa księga przysłów... Krzyżanowskiego ${ }^{25}$.

Omawiane rosyjskojęzyczne imię bardzo często w ramach jednej paremii występuje w parze z imieniem Еремей lub z jego wariantami: Ермий / Ерёма / Еремий / Ерёмка / Ерёмушка oraz wyrazami pochodnymi: ерёмин, ерёмины (w materiale słownikowym zarejestrowano około 40 jednostek $z$ tym imieniem). Imię pochodzenia biblijnego od imienia Иеремия / Jeremiasz, co z kolei od hebr. והימר' 'wywyższony przez boga Jahwe'. Imię to występuje w powiedzeniach i przysłowiach charakteryzujących przeróżne ludzkie cechy, jak również zjawiska natury przyrodniczej, najczęściej związane z kalendarzem prac polowych:

\section{Głupota - rozum}

Всяк Еремей про себя разумей

Сунуло Ерёмушку к семи чертям

Фома не без ума, Ерёма не без промысла

\section{Upór}

Ерёма в воду, Фома ко дну: оба упрямы, со дна не бывали

\section{Swoje - cudze}

Ерёма, Ерёма! сидел бы ты дома да точил веретёна!

Еремеевы слёзы о чужом пиве/добре льются.

Указчик Ерёма, указывай дома!

25 J. Krzyżanowski (red.), Nowa księga przysłów i wyrażeń przysłowiowych polskich..., t. 3, s. 519. 


\section{Kalendarz prac polowych}

Еремея (Ермия) опусти сетево, покинь сетево (севалку).

Еремея подыми сетево (1 мая) и Еремея (Ермия) опусти сетево (31 мая; tzn. początek i koniec zasiewów)

\section{Pijaństwo}

Фома на гудке играть, а Ерёма глазами мигать

Пей, Еремей, да ума не пропей!

\section{Prawda - przypuszczenie}

Ведают о Ерёме в большой хороме

Sens - brak sensu

Живёт Домка за Ерёмкой

Dwór - dom - gospodarstwo

Наш Ерёма не сказался дома

W języku polskim odnotowaliśmy tylko jedno powiedzenie z tym imieniem - (kto) lamentuje jak Jeremiasz.

Pod względem wysokiej frekwencji w materiale rosyjskim odznacza się także imię Семён і jego warianty: Сеня / Сенька / Сенюшка / Сенушка / Сёмка / Сенька Семён / Сенушка Симон /Симеон - 64 jednostki paremiologiczne według słownika Kowszowej, przy czym spora ich część to składniowo tożsame konstrukcje różniące się poszczególnymi elementami leksykalnymi. Imię to wywodzi się od hebr. שמעון 'usłyszany' i obecne jest w paremiach charakteryzujących takie cechy i zjawiska, jak:

\section{Rozum - głupota}

Годится под св. Симеона столпника

Умён как поп Семён: книги продал, а карты купил

Всяк Семён про себя умён

Swoje - cudze

Людской Семён как лук зелён, а наш Семён из грязи свалён

Prostota - przebiegłość

Коли поп Сеньку не обманет, так и Сенька попу правды не скажет

\section{Pomoc - odpowiedni moment}

По Ерёме шапка, по Сеньке кафтан

По Сеньке и Шапка, по бабе и шлык

По Сеньке и Шапка, по боярину хохол

\section{Bogactwo - ubóstwo}

У Сенюшки денежки - умной Семён, а как нет, дескать, денежек - глуп, не умён.

Были денежки - любили Сеню девушки, а не стало денежекзабыли Сеню девушки 
W polskim materiale odpowiednik rosyjskiego imienia - Szymon - występuje w kilku paremiach odnoszących się wyłącznie do przepowiedni i wróżb pogodowych: Deszcz po Szymonie i Tadeuszu pada, ostra zimę zapowiada; Kiepski rok zapowiada, gdy na Szymona nie pada; Na Szymona i Judy boi się koń grudy; Na świętego Szymona babie lato kona; Od świętego Szymona nie wdziewaj już kaftana.

Do imion częstych w rosyjskich przysłowiach i powiedzeniach należy także Сава wraz z licznymi wariantami: Саввa / Савваmuй /Савка / Савушка і pochodnymi od nich derywatami przymiotnikоwymi саввины oraz czasownikowymi саввить, просаввиться (wydać wszystkie pieniądze na jarmarku w dzień św. Saby) - 34 zarejestrowane jednostki w słowniku Kowszowej. Imię pochodzi

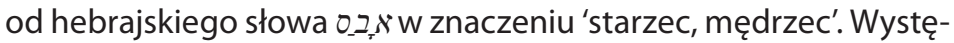
puje w przysłowiach i powiedzeniach odnoszących się do następujących sfer tematycznych:

\section{Kalendarz prac polowo-gospodarskich}

Савва стелет. Савва гвозди острит. Савва засалит

Савватия пчельника, пчеловода

Świadomość - poszlaka

Савва съел сало, уперся, заперся, сказал: не видал

Wina - zasługa

Каков Савва, такова ему и слава

Sława - szacunek

Учестили Савву ни в честь, ни в славу

Przeszłość — teraźniejszość

Тот же Савка, на тех же санках

\section{Pomoc - odpowiedni moment}

Схватился Савва, как жена сшила саван

W języku polskim nie zanotowaliśmy jednostek paremiologicznych z tym imieniem.

Wysoką frekwencją w rosyjskim materiale odznacza się także imię Мария wraz z jego wariantami pochodnymi Марья / Маша / Машка / Манька, Манюшка / Маняшка / Марья-Марина. Imię proweniencji biblijnej, w rosyjskim spotykane także w warianсіе Мариам / Мириам / Марьям wywodzące się od hebrajskiego słowa םיר 'być pięknym, wspaniałym' lub 'ukochana, upragniona'. Słownik Kowszowej rejestruje 33 jednostki paremiologiczne z tym imieniem, niejednokrotnie w parze z męskim imieniem Иван. Występuje ono najczęściej w powiedzeniach i przysłowiach odnoszących się do następujących zjawisk: 


\section{Fama - Sława}

Иван был в Орде, а Марья вести сказывает

Nazwa - imię - przezwisko

Иван Марье обычный друг

Иван Марье не товарищ. Иван Марье обычный друг

Сашенька, Машенька - фу, пропасть какая!

Сашки - канашки, Машки - букашки, Маринушки-разинюшки

Los - cierpliwość - nadzieja

Не у всякого жена Марья — кому Бог даст

Pomoc - odpowiedni moment

Иван Марьи не слушается: сам приказывать горазд

Swoje - cudze

Хороша Мама, да не наша

Praca - próżnowanie

Что Машка напряла, то мышка скрала

Spokój - ruch

Полетел от Машки вверх-тормашки

Pochopność - roztropność

И на Машку живет промашка. Живет и на Машку промашка

\section{Sens - brak sensu}

Сашка, позови Машку; Машка, подай платок, -

а платок подле боку

W polskim materiale występują nieliczne powiedzenia związane, jak większość omówionych do tej pory, z przesądami i wróżbami pogodowo-przyrodniczymi: Maria się rodzi, jaskółka odchodzi; w Narodzenie Pannyl Marii pogodnie, tak będzie cztery tygodnie. Niska frekwencja tego imienia w polskim zasobie paremiologicznym wynika zapewne z okoliczności, że imię Maria (także Maryja) w polskiej kulturze, jako zarezerwowane głównie dla Matki Boskiej, podlegało pewnemu tabu, w związku z czym nie nadawano go zbyt często, zastępując formami pochodnymi Marianna, Maryna, Marzena, lud. Marzanna. Stąd większa liczba paremii z tymi wariantami: Jak nie ma panny Marianny, dobra i Maryśka; Jaś Maryni buty kupił i odebrał, jak się upił; Każda Maryna może mieć syna; Marzenia ze wsi, a latecko do wsi (topienie Marzanny i powitanie wiosny).

Nieco mniejszą w aktywność w materiale rosyjskim wykazuje imię Яков wraz z formami hipokorystycznymi Яика, Ягуn - 31 jednostek w słowniku Kowszowej. Imię pochodzenia biblijnego od hebr. בקע' 'pięta'. Przysłowia odnoszą się do następujących bloków tematycznych: 
Jedzenie

Яков лаком, съел кошку с маком.

Рад Яков, что пирог с мако

\section{Pogoda}

Яков, брат Божий, крупииу пошлёт (крупу, град)

\section{Różnorodność - jedność}

От Якова недалеко до всякого

Prawda - kłamstwo

Всякому по Якову (т. е. всем равно)

Los - nadzieja

Ивсякому, да не как Якову

Przyzwoitość - ogłada - obyczaj

У солдата Яшки таковы замашки

W języku polskim zarejestrowaliśmy 13 paremii z imieniem Jakub, które w większości związane są z przesądami i przepowiedniami pogodowo-rolnymi: Deszcze na świętego Jakuba, na pszenicę pewna zguba; Dzień świętego Jakuba przed wschodem pogodny, że napełnisz gumna, masz znak niezawodny; Gdy deszcz w święty Jakub będzie, zgina na dębach żołędzie; Jaki Jakub do południa, taka zima też do grudnia; Leje od Jakuba do Ignaca - stracona rolnika praca; Na Filipa i Jakuba, gdy przymrozek spadnie, najgorsza zaraza na zboże przypadnie; Na Jakuba deszcz, złych żniw wieszcz; Na święty Jakub chmury, będa śniegu fury; Jak Kuba bobowi, tak bób Kubie (o terminie siewu bobu). Ostatnie przysłowie, zdaniem Dobrosławy Świerczyńskiej, jest wynikiem gry językowej i żartobliwej modyfikacji pierwotnego powiedzenia Jak Kuba Bogu... ${ }^{26}$. Imię to występuje także w przysłowiach związanych z takimi pojęciami, jak:

\section{Dostatek}

Jak święty Jakub nadejdzie, to nam biedy nie będzie

\section{Pijaństwo}

Przepił Kuba rolę, pod kościołem siada, kto gorzałkę pije, ten wyjdzie na dziada

\section{Wzajemne relacje}

Jak Kuba Bogu, tak Bóg Kubie,

Jak Kuba krowie do żłobka, tak krowa Kubie do szkopka

W materiale rosyjskim imię Адaм posiada zbliżoną frekwencję jak antroponim Яков (29 jednostek wg słownika Kowszowej). Imię

26 D. Świerczyńska, Wolnoć dupce w swej chałupce (Językowe gry przysłowiowe), „Teksty Drugie” 1996, nr 2-3, S. 241. 


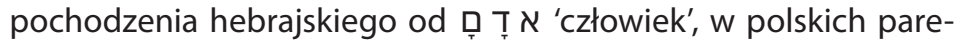
miach spotykane także w postaci dialektalnej i archaicznej Jadam (Jakna Jadama nań). W rosyjskich jednostkach paremiologicznych spotykane także w wariancie zapelatywizowanym адам (И ты адам, и я адам, все мы адамы). Jako imię jednej z najbardziej znanych postaci biblijnych — na równi z Ewq — często spotykane jest w przysłowiach i powiedzeniach odwołujących się do motywów z Pisma Świętego o grzechu pierworodnym i wygnaniu z raju, choć na gruncie języka rosyjskiego i polskiego nabierają one bardziej uniwersalnego wydźwięku, odnosząc się do oceny określonych ludzkich czynów i zachowań oraz ich konsekwencji, np. ros. Адам грех сотворил - рай затворил; Адам Еву послушал, да яблочко скушал; Адам заключил древом, а Ева выстрадала чревом; Адам прельщён женою, жена змеёю, а оба вон из рая; Адам согрешил, а мы воздыхаем; Женою и Адам из рая изгнан; pol. Adam zjadł jabłko, a nam skomę uczynit; Adam zmawia na Ewę, na Adama Ewa - a oboje jedli z drzewa; Dla jabłuszka tylko Adam grzech na nas włożył. Wśród polskich przysłów tradycyjnie pojawiają się przysłowia kalendarzowe z parą antroponimów Adam i Ewa: Adam i Ewa pokazujq, jaki styczeń i luty po nich następujq; Gdy w dzień Adama i Ewy mróz i pięknie, zima wcześnie pęknie; Na Adama, Ewy czas przyszyć cholewy; Na Adama pięknie, jutrzenka jasna, będzie stodoła ciasna; Na święty Adama, Ewy dobre bydłu plewy; w dzień Adama i Ewy daruj bliźnim gniewy. Zarówno w rosyjskim, jak i polskim materiale paremie z interesującym nas imieniem odwołują się poprzez symbol Adama - jako pierwszego człowieka - do czasów odległych, pradawnych, sytuacji i zdarzeń, które zaszły dawno temu: ros. Адамовы лета с начала света; pol. Od czasów Adama i Ewy; Kiedy się Adam do Ewy zalecat (tzn. bardzo dawno temu - M.W.). W obu badanych językach postać biblijnego Adama ${ }^{27}$ występuje jako symbol praprzodka wszystkich ludzi, pierwszego człowieka, np. ros. Все адамовы детки; Все адамовы детки, все на грехи падки; pol. Z Adamowego idziemy wszyscy rodu.

Mniejszą częstotliwość w materiale rosyjskim wykazały pare-

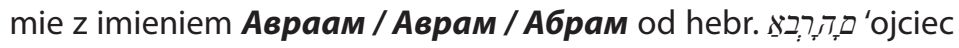
wzniesiony' (21 jednostek wg słownika M. Kowszowej, przy czym niektóre paremie dublują się). Imię funkcjonujące w języku polskim w postaci Abraham, a w przysłowiach także w postaci hipokorystycznej Abrahamek. W rosyjskich przysłowiach odnosi się do następujących kręgów tematycznych:

27 Należy zauważyć, że w Biblii słowo adam używane jest najczęściej w znaczeniu apelatywnym jako określenie człowieka lub zbiorowości ludzi. w funkcji antroponimu i zarazem imienia własnego użyte jest tylko 5 razy (zob. I. Marković, Wielka księga imion..., s. 22). 


\section{Wina - zasługa}

По бороде - Авраам, а по делам - Хам

Dwór - dom - gospodarstwo

Хозяин в дому, как Авраам в раю

\section{Pochopność - roztropność}

Сам Абрам дался в обман

\section{Różnorodność - jedność}

Абрам, Абрам, да не Божий же храм

Ponadto w rosyjskich jednostkach występują bezpośrednie odwołania do postaci biblijnych i związanych z ich udziałem wydarzeń, np. Авраам, оставя дом, молился за Содом; Адам да Авраам жёнами славны: едина смехом, а другая грехом; Аврааму отеи Фара, а жена ему Сарра; Авраам гулял по горам, а Адам крылся по норам; Авраам иному богу голову сломил. W materiale rosyjskim odnajdujemy także derywat czasownikowy авраамиться w powiedzeniu Не авраамься, не исаакся, не иаковься ('nie bądź przesadnie bogobojny, religijny'). Materiał polski reprezentują pojedyncze paremie odwołujące się do pijaństwa: kto spotkał się z Abramkiem ('upił się'), śmierci: Pójść do Abrahama (na łono, piwo) ('umrzeć'), wieku: kto uwidział Abrahama ('przekroczył wiek 50 lat'), pogody: Jak nie będziem prosić Abrahama, to nam ziemia nie zrodzi sama (do św. Abrahama modlono się z prośbą o deszcz lub pogodę).

Analiza zebranego materiału słownikowego pozwoliła zauważyć niewielką aktywność w rosyjskim zasobie paremiologicznym jednostek z imieniem Михаил oraz jego formami pochodnymi w odróżnieniu od języka polskiego, w którym imię Micha ${ }^{28}$ i jego formy hipokorystyczne, głównie Michałek oraz w postaci zapelatywizowanej michałek, pojawiają się stosunkowo często (47 jednostek wg Nowej księgi... Krzyżanowskiego). Są to przeważnie przysłowia kalendarzowe: Jaki Michał, taka wiosna; Święty Michat do szkół wpycha; Na Michała łowcy chwała; Gdy noc jasna na Michała, to nastapi zima trwała; Gdy na Michała i Wacława jasno, nie będzie w zimie ciasno; Grzmot w dzień świętego Michała, żywność przyszła, Bogu chwała; Jeśli święty Michał deszczem nie służy, dobra to i sucha wiosnę wróży; Po świętym Michale niech każdy od swego nie daje; Po świętym Michale Pan Bóg wszędzie daje; Po świętym Michale wolno paść i na skale; Ptaszki do Michała gdzieś zima została; Święty Mi-

28 Szerzej na temat imienia Michał zob. B. Walczak, Michał w polskich przysłowiach i porzekadłach, ,"Literatura ludowa" 1992, nr 4-5, s. 44-52; R. Kucharzyk, o gwarowych apelatywach odantroponimicznych (na przykładzie leksemów zwiq̨zanych z imieniem Michał), „Acta Universitatis Wratislaviensis” 2015, nr 3705, t. 25, s. 89-102. 
chał będzie ludki do kopy spychał; Święty Michał będzie ogorzeliznę spychał; Święty Michał blisko, posiałeś już wszystko? w Michał, kiedy deszcze wszędzie, cała zima lekka będzie; Zbytek na święty Michał żołędzi wiele śniegu w Boże Narodzenie napędzi; Święty Michał śniegiem kichał. Oprócz przysłów kalendarzowych w materiale polskim zarejestrowaliśmy jednostki odnoszące się do takich cech ludzkich i zjawisk, jak:

\section{Głupota}

Mówisz jako prawy Michał (tzn. mówisz bzdury, głupoty)

kto ma michałki w głowie (tzn. jest niezbyt mądry)

\section{Nieprawdopodobieństwo}

Jeszcze tego nikt nie słychał, żeby babie było Michał

\section{Osiąganie i otrzymywanie określonych korzyści}

Bierz, Michale, co Bóg daje

Większość imion wyłonionych w strukturze analizowanych paremii, szczególnie rosyjskich, niejednokrotnie utraciła, jak wspominaliśmy we wstępie, swój związek z pierwotnymi biblijnymi ich nosicielami oraz tradycyjnie przypisywanymi im cechami charakteru, zyskując na gruncie badanych języków swoją odrębną symbolikę i semantykę (np. Фома, Ерёма, Семён, Мария, Савва; Мichał). Wyjątek stanowią imiona Adam / Адам i Ewa / Eвa, po części także Яков/Jakub і Авраам w języku rosyjskim.

Porównanie obu języków pozwala stwierdzić znacznie większą aktywność imion hebrajskiego pochodzenia w języku rosyjskim, jak również większą ich asymilację, co przejawia się szczególnie w obecności derywatów, np. czasownikowych (не исаакся, не авраамься, не иаковься; просаввиться), przymiotnikowych (адамовы, саввины), a także różnorodności pochodnych hipokorystycznych i apelatywnych. Mała ich frekwencja w materiale polskim może wynikać, po pierwsze, z okoliczności, o której wspominaliśmy we wstępie, a mianowicie w rosyjskiej lingwokulturze imiona pełnią nie tylko funkcję czysto nazewniczą, identyfikacyjną, indywidualizującą, lecz także charakteryzującą, często pod wpływem ludowo-folklorystycznych wyobrażeń o nosicielach różnych imion.

Po drugie, imiona hebrajskie w polskich przysłowiach i powiedzeniach, w zdecydowanej większości pochodzenia biblijnego, kojarzone były ze staro- i nowotestamentowymi postaciami i jako dla nich zarezerwowane wiązały się ze sferą sacrum. Użycie ich w przysłowiach i powiedzeniach, nierzadko o wydźwięku humorystycznym, żartobliwym, ludowo-jarmarcznym mogło być 
postrzegane jako naruszenie sfery sacrum i profanacja imion biblijnych świętych. Stąd też częsta obecność imion pochodzenia hebrajskiego w polskich powiedzeniach i przysłowiach kalendarzowych związanych najczęściej z przepowiedniami pogodowymi i cyklami agrarno-rolnymi, w wydźwięku swoim neutralnych i obyczajowo bezpiecznych.

Po trzecie, ogólnie niższa częstotliwość imion hebrajskich w polskiej paremiologii może być również konsekwencją tego, że Polacy przez pewien czas nie nadawali dzieciom imion starotestamentowych ${ }^{29}$, być może jako konsekwencja pewnych antysemickich nastrojów. $Z$ tego powodu imiona te nie funkcjonowały w codziennym obiegu językowym Polaków na tyle aktywnie, aby ulegały naturalnym w sytuacji ciągłego użycia procesom rozwoju znaczeń wtórnych, wzrostowi potencji derywacyjnej oraz utrwaleniu w strukturze przysłów, powiedzeń i innych jednostek idiomatycznych. 